\title{
PERBEDAAN TINGKAT KECEMASAN ANTARA PASIEN LAKI- LAKI DAN PEREMPUAN PADA PRE OPERASI LAPARATOMI DI RSUP. PROF.Dr.R.D. KANDOU MANADO
}

\author{
Wayan Erawan \\ H. Opod \\ Cicilia Pali
Bagian Psikologi Fakulatas Kedokteran Universitas Sam Ratulangi Manado
Email: wayanerawan@yahoo.co.id

\begin{abstract}
Abstrak: Kecemasan adalah suatu sinyal yang menyadarkan, ia memperingatkan bahaya yang mengancam dan memungkinkan seseorang mengambil tindakan untuk mengatasi ancaman. Angka kejadian dari kecemasan perioperative diketahui 11\% - 80\% diantara pasien dewasa. Tujuan penelitian untuk mengetahui perbedaan proporsi pasien laki-laki dan perempuan pre operasi laparatomi yang mengalami kecemasan, dan mengetahui perbedaan tingkat kecemasan pasien laki-laki dan perempuan pre operasi laparatomi. Jenis penelitian ini adalah penelitian analitik dengan pendekatan cross sectional. Pengambilan sampel dengan teknik non probability sampling yaitu consecutive sampling. Metode pengumpulan data dengan menggunakan kuesioner Hamilton Anxiety Scale (HARS). Penelitian dilakukan pada 32 responden di RSUP Prof.dr.R.D.Kandou Manado pada bulan november sampai desember 2012. Analisis data menggunakan uji statistik yaitu independent sampel T-Test. Hasil penelitian didapatkan responden laki-laki, tidak cemas (40\%), cemas ringan (26,67\%), cemas sedang (33,33\%), sedangkan pada responden perempuan diperoleh hasil, tidak cemas (23,53\%), cemas ringan (17,65\%), cemas sedang (35,29\%), cemas berat (23,53\%). Berdasarkan uji statistik nilai P-value sebesar 0,024, berarti HO ditolak dan Ha diterima, artinya ada perbedaan tingkat kecemasan antara pasien laki-laki dan perempuan pre operasi laparatomi.
\end{abstract}

Kata kunci: Kecemasan, laparatomi, laki-laki, perempuan.

\begin{abstract}
Anxiety is a signal that disenchants; warns threatening dangers and gives someone the chance to take action in order to overcome the incoming threats. The incidence of perioperative anxiety has been reported with range $11 \%$ to $80 \%$ among adult patients. The study objective is to determine the difference in proportion between male and female prelaparotomy surgery patients who experience anxiety, and know the difference in the level of anxiety of male and female pre-laparotomy surgery patients. This observation is an analytic study with cross sectional approach. The sampling technique is by using non probability sampling; which is consecutive sampling. The data colletion method is by using questionnaire, Hamilton Anxiety Scale (HARS). The observation was done toward 32 respondents in Prof.dr.R.D.Kandou General Hospital from November to December 2012. The data analysis is by using statistical test; independent sample T-test. The observation among male respondents results in without anxiety (40,\%), with mild anxiety (26,67\%), with moderate anxiety (33.33\%), while among female respondents results in without anxiety (23.53\%), with mild anxiety (17.65\%), with moderate anxiety (35.29\%), and with severe anxiety (23.53\%). According to the statistical test, resulting in P-value of 0.024 , that $\mathrm{HO}$ is rejected and Ha is accepted. In conclusion, there are differences in the level of anxiety between male and female pre-laparotomy surgery patient.
\end{abstract}

Keyword: anxiety, laparotomy, male, female. 
Kecemasan adalah suatu sinyal yang menyadarkan; ia memperingatkan adanya bahaya yang mengancam dan memungkinkan seseorang mengambil tindakan untuk mengatasi ancaman. ${ }^{1}$ Pasien yang menjalani operasi akan mengalami keadaan psikologi akut berupa keadaan yang sulit atau kesedihan. Angka kejadian dari kecemasan perioperative telah dilaporkan antara dari $11 \%$ - 80\% diantara pasien dewasa. ${ }^{2}$ Karakteristik demografik yang berhubungan dengan kecemasan pre operasi adalah jenis kelamin. Dan jenis kelamin perempuan lebih besar resiko untuk terkena kecemasan pre operasi. ${ }^{2}$ Cemas pada pasien yang akan dilakukan tindakan operasi juga tergantung pada jenis operasinya. Operasi besar akan memberikan stressor yang lebih besar pada pasien dan hal ini akan dapat meningkatkan kecemasan. Salah satu jenis operasi besar yang dilakukan adalah laparatomi. ${ }^{3}$ Laparatomi merupakan insisi pembedahan melalui pinggang, tetapi tidak selalu tepat dan lebih umum dilakukan dibagian perut mana saja. ${ }^{4}$ Di rumah sakit Prof. dr.R.D. Kandou Manado, pada bulan oktober 2012 dibagian rawat inap Irina $A$ atas dan bawah, jumlah pasien post laparatomi tercatat sebanyak 43 pasien, laki-laki sebanyak 25 dan perempuan berjumlah 18 pasien.

\section{TUJUAN PENELITIAN}

Secara umum penelitian ini bertujuan untuk mengetahui perbedaan tingkat kecemasan pasien laki-laki dan perempuan pre operasi laparatomi di RSUP. Prof. dr.R.D. Kandou Manado.

\section{METODE}

Penelitian ini merupakan jenis penelitian analitik dengan pendekatan Cross Sectional. Pengambilan sampel dengan teknik non probability sampling yaitu consecutive sampling. Metode pengumpulan data dengan menggunakan kuesioner yaitu Hamilton Anxiety Scale (HARS). Penelitian dilakukan pada 32 responden di RSUP Prof.dr.R.D.Kandou Manado pada bulan november sampai desember 2012. Analisis data menggunakan uji statistik yaitu independent sampel T-Test.

\section{HASIL}

Pada penelitian ini, didapatkan gambaran tingkat cemas berdasarkan jenis kelamin (tabel 1) dan grafik proporsi tingkat cemas berdasar jenis kelamin (gambar 1).

Pada tabel dapat diketahui bahwa proporsi responden laki-laki tidak cemas (40\%), cemas (60\%), sedangkan responden perempuan cemas tidak cemas $(23,53 \%)$, cemas $(76,47 \%)$.

Tabel 1. Distribusi frekuensi tingkat cemas pada laki-laki dan perempuan.

\begin{tabular}{ccccccc}
\hline Tingkat cemas & $\begin{array}{c}\text { Laki-laki } \\
\text { Jumlah }\end{array}$ & $\mathbf{( \% )}$ & $\begin{array}{c}\text { Perempuan } \\
\text { Jumlah }\end{array}$ & $\mathbf{( \% )}$ & $\begin{array}{c}\text { Total } \\
\text { Jumlah }\end{array}$ & (\%) \\
\hline Tidak cemas & 6 & 40,00 & 4 & 23,53 & 10 & 31,25 \\
Ringan & 4 & 26,67 & 3 & 17,65 & 7 & 21,88 \\
Sedang & 5 & 33,33 & 6 & 35,29 & 11 & 34,38 \\
Berat & - & - & 4 & 23,53 & 4 & 12,50 \\
Sangat Berat & - & - & - & - & - & - \\
Total & 15 & 100 & 17 & 100 & 32 & 100 \\
\hline
\end{tabular}




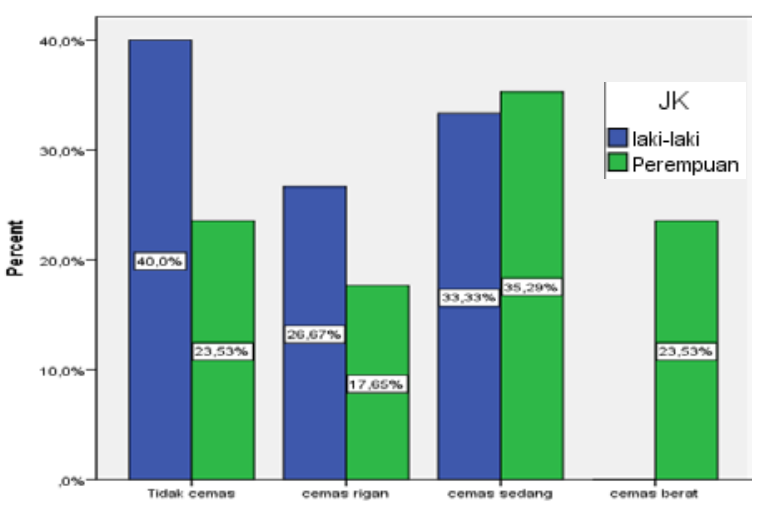

Gambar 1. Grafik tingkat kecemasan berdasarkan proporsi jenis kelamin.

Tabel 2. Hasil uji t

\begin{tabular}{cccccc}
\hline JK & $\begin{array}{c}\text { Mean } \\
\text { Deviation }\end{array}$ & $\begin{array}{c}\text { Std. } \\
\text { Error } \\
\text { Mean }\end{array}$ & $\begin{array}{c}\text { P } \\
\text { value }\end{array}$ & N \\
\hline Laki-laki & 14,13 & 4,719 & 1,218 & & 15 \\
Perempuan 19,47 & 7,469 & 1,811 & 0,024 & 17 \\
\hline
\end{tabular}

Dari hasil penelitian didapatkan bahwa rata-rata tingkat kecemasan responden lakilaki adalah 14,13 dengan standar deviasi 4,719, sedangkan untuk perempuan ratarata tingkat kecemasannya adalah 19,47 dengan standar deviasi 7,469. Hasil uji statistik didapatkan nilai $\mathrm{p}=0,024$, berarti pada alpha $5 \%$ terlihat adanya perbedaan yang signifikan rata-rata tingkat kecemasan responden pasien laki-laki dengan responden pasien perempuan. Dengan hasil seperti diatas berarti pada penelitian ini, $\mathrm{Ha}$ diterima dan $\mathrm{HO}$ di tolak artinya ada perbedaan tingkat kecemasan antara pasien laki-laki dan perempuan pre operasi laparatomi.

\section{BAHASAN}

Pada penelitian ini didapatkan bahwa perempuan (76,5\%) lebih banyak mengalami kecemasan dibandingkan laki laki (60,0\%). Hasil ini sejalan dengan hasil penelitian yang didapatkan oleh Wojciech dkk, bahwa kecemasan yang berhubungan dengan operasi lebih sering dialami oleh perempuan, yang menunjukkan bahwa jenis kelamin perempuan merupakan faktor terjadinya kecemasan pre operasi pada orang dewasa. Perempuan lebih mudah menunjukkan kecemasan yang dialaminya dibandingkan laki-laki. ${ }^{5}$

Kecemasan mengenai prosedur operasi dapat tercermin dalam banyaknya gejala psikologi pada periode pra operasi dan pasca operasi. Kecemasan pasien paling tinggi adalah sebelum operasi, segera menurun setelah operasi, dan meningkat kembali pasca operasi. ${ }^{6}$

Dalam studi terbaru, angka prevalensi kecemasan ditemukan berkisar antara 11\% sampai $80 \%$ di kalangan pasien dewasa. Suatu studi menunjukkan bahwa 62\% pasien menderita kecemasan pra operasi; perempuan lebih banyak daripada laki-laki, dan lebih sering setelah operasi intraabdominal. Kecemasan pra operasi dipengaruhi oleh kekhawatiran pasien tentang kesehatan umum mereka; ketidakpastian tentang masa depan, jenis operasi dan anestesi yang akan dilakukan; ketidak nyamanan dan nyeri pasca operasi, ketidakmampuan, kehilangan kebebasan, dan takut mati. ${ }^{6}$

Kecemasan pasien dapat diturunkan dengan harapan hasil positif dan dengan dukungan sosial yang diberikan kepada pasien. Menurut Palapattu dkk faktor demografi seperti jenis kelamin, usia, dan status perkawinan tidak berhubungan bermakna dengan prevalensi kecemasan. Sejalan dengan hasil penelitian Palapattu dkk, Maward dan Azard menemukan bahwa tidak ada hubungan bermakna antara tingkat kecemasan pra operasi dengan jenis kelamin. Sebaliknya, Nijkamp dkk menemukan bahwa jenis kelamin mempengaruhi tingkat kecemasan pasien.,7

Beberapa peneliti setuju bahwa kurangnya informasi yang adekuat dan tepat waktu, merupakan faktor terjadinya kecemasan pasien. Konsultasi bagi mereka yang akan menjalani operasi mampu menurunkan kecemasan pasien. Sebuah studi oleh Kiyohara dkk menemukan bahwa pasien yang menerima informasi pra anestesi dengan baik selama kunjungan dengan ahli anestesi menunjukkan penurunan kecemasan dibandingkan dengan 
mereka yang tidak menerima informasi. Selain itu, penelitian yang dilakukan oleh Jaquelyn dkk menemukan bahwa jenis kelamin perempuan meningkatkan risiko hingga lima kali lebih banyak mengalami kecemasan dibandingkan dengan jenis kelamin laki-laki. ${ }^{8}$

Pada penelitian ini, tingkat kecemasan kategori tidak cemas lebih banyak pada laki-laki demikian juga dengan tingkat kecemasan kategori ringan, dibandingkan dengan perempuan. Sebaliknya tingkat kecemasan kategori sedang dan berat lebih banyak pada perempuan. Hasil analisis bivariat menunjukan bahwa nilai rata-rata skor kecemasan pada perempuan lebih tinggi daripada laki-laki $(\mathrm{p}=0,024)$. Hal ini menunjukan bahwa perempuan mengalami kecemasan dengan tingkat yang lebih tinggi dibandingkan dengan laki-laki. Hasil ini sejalan dengan hasil penelitian yang didapatkan oleh Abdul-Rasoul A, bahwa kecemasan dengan tingkat yang lebih tinggi lebih banyak pada perempuan disemua jenis operasi. ${ }^{9}$ Demikian juga hasil penelitian yang didapatkan oleh Nijkamp dkk, bahwa perempuan lebih sering mengalami kecemasan tingkat yang lebih tinggi dibandingkan laki-laki sebelum operasi. ${ }^{7}$

\section{SIMPULAN}

Berdasarkan hasil penelitian ini, dapat disimpulkan bahwa perempuan lebih banyak mengalami kecemasan daripada lakilaki. Perempuan mengalami kecemasan dengan tingkat yang lebih tinggi daripada laki-laki.

\section{DAFTAR RUJUKAN}

1. Kaplan HI, Sadock BJ, Grebb JA, Sinopsis psikiatri. Jakarta: Binarupa Aksara Publisher, 2010; p.19-31.

2. Caumo W, Schmidt AP, Schineder CN, Bergmann J, Iwamoto CW, Bandera D, et al. Risk factors for preoperative anxiety in adults. Acta Anaesthesiologica Scandinavica. 2001;45:298-307.

3. Surono. Perbedaan Tingkat kecemasan klien pria dan wanitaa pre operasi laparatomi di rumah sakit Roemani Semarang [skripsi]. Semarang: Universitas Muhammadiah Semarang; 2007.

4. Dorland WA Newman. Kamus kedokteran Dorland. Jakarta: Penerbit buku kedokteran EGC; 2002.

5. Wojciech R, Andrzej K, Pawel S, Olga S. Preoperative anxiety assessed by questionnaires and patient declarations. anaesthesiology intensive therapy XLI. 2009;80-4.

6. Erci B, Sezgin S, Kacmaz Z. The impact of therapeutic relationship on preoperative and postoperative patient anxiety. Australian Journal of Advanced Nursing. 2008;26:59-66.

7. Nijkamp M, Kenens C, Dijker A, Ruiter R, Hiddema, F, Nuijts R. Determinants of surgery related anxiety in cataract patients. The British Journal of Ophthalmology. 2004;88:1310-14.

8. Jaquelyn V, José RB, José MO. Anxiety in preoperative anesthetic procedures. anxiety in preoperative anesthetic procedures. Cir Cir. 2010;78:147-51.

9. Abdul-Rasoul A. Pre-operative anxiety in patients undergoing different types of surgery comparative study. J Fac Med Baghdad. 2008;50. 